\title{
Amana's First Decisions about Roadside Architecture
}

\author{
An Index of Cultural Change
}

\author{
KEITH A. SCUlLE
}

AMANA'S GREAT CHANGE in 1932 was a momentous cultural event. It marked the end of the communal economy essential to Amana for ninety years, the adoption of capitalism, and the separation of Amana's economic and religious leadership. The Great Change has become the most controversial event in the recent literature about Amana. ${ }^{1}$ Perhaps this is explained by the fascination social turning points hold for students of culture: crises force extraordinary choices from individuals and groups and reveal their views of the past and plans for the future. Times of rapid change are fertile grounds in which to form an analysis of a culture. In this regard, just before and during the Great Change Amana's choices of architectural styles for its first roadside buildings - the garage at South Amana and the oil stations at Homestead and Main Amanareveal the success of a pragmatic and conservative leadership in preserving cultural traces.

Amana evolved as a folk culture. Its population was distinct, homogeneous, self-perpetuating, and largely selfsufficient, although not entirely independent of the surrounding society. ${ }^{2}$ Its identity was rooted in religion. As one of several

1. Jonathan Gary Andelson, "Communalism and Change in the Amana Society, 1855-1932" (Ph.D. diss., University of Michigan, 1974); Jonathan G. Andelson, "The Double Bind and Social Change in Communal Amana," Human Relations 34 (1981), 111-125; Lawrence L. Rettig, Amana Today: A History of the Amana Colonies from 1932 to the Present (n.p., 1975); Bertha M. H. Shambaugh, Amana That Was and Amana That Is (Iowa City, 1932); Barbara S. Yambura, A Change and a Parting: My Story of Amana (Ames, 1960).

2. Henry Glassie, Pattern in the Material Folk Culture of the Eastern United States (Philadelphia, 1968), 3. 
Pietist sects born in reaction to the established and hierarchical German Lutheran church, the forerunners of Amana believed in the revolutionary effect of continual and direct interaction with God through an inspired leader (Werkzeug), and organized as the Community of True Inspiration in 1714 near Frankfort, Germany. The group drew members from elsewhere in the Germanies and Switzerland, and centered in eight settlements by the early nineteenth century.

Differences from normative society heightened thereafter. Between 1823 and 1843, membership increased and gathered in four large Hessian estates with independent Inspirationist economic and political goals. Political and religious persecution by the government, however, combined with financial difficulties to force relocation. Werkzeug Christian Metz prophesied relocation, and between 1843 and 1846 eight hundred Inspirationists settled as the Ebenezer Society in six economically independent villages near Buffalo, New York. The communal economy, for which the Community later gained so much attention, was formally adopted in 1846 partly to distinguish it from the capitalist society prevailing outside. ${ }^{3}$

The Society manipulated space to foster its separate identity. Although its original precepts had recommended against communication among Inspirationists as well as between them and society at large, these preachments were first practiced at Ebenezer. There, the governing Elders developed the doctrine of isolation, which restricted communication with outsiders. Failure to prevent contact with nearby worldly Buffalo, nevertheless, coupled with the high price of land, again forced resettlement. In keeping with their folk practice, the Community's relocation was ordered by Werkzeug inspiration. Between 1855 and 1861, seven villages were founded in Iowa and collectively named Amana (believe faithfully) to signify the Community's determination to persist. ${ }^{4}$

In Iowa, the Community adhered to the doctrine of isolation. ${ }^{5}$ The founders included within the original eighteen54.

3. Andelson, "Double Bind," 121; Andelson, "Communalism," 43-44,

4. Andelson, 'Double Bind," 121; Shambaugh, 71.

5. Darrell H. Davis, "Amana: A Study of Occupance," Economic Geography 12 (1936), 220. 
thousand-acre tract the diverse elements necessary for an independent community: potable water, tillable land, mature woods, and ample clay and stone deposits. They also purchased the holdings of all outsiders within the perimeter of the settlement. Middle Amana, East Amana, West Amana, South Amana, High Amana, and Homestead were founded within a six-mile radius of the original village known as Old Amana, Main Amana, or frequently merely Amana. East Amana grew at the edge of Johnson County but the other villages dominated Amana Township in adjacent Iowa County. Although Amana contributed to the state's public school fund, Amana's domination of the township permitted the Society to maintain its own schools, employ teachers, and set curricula. ${ }^{6}$ Control was consolidated within Amana. No Amanites were politically active outside. Each village became a self-sustaining unit governed by a Council of Elders (Bruderrath) appointed by the Board of Trustees of the Amana Society, incorporated in 1859. The theocratic board directed the Community's religious life and its internal business affairs as well as those with the world outside. Some materials and foodstuffs were purchased outside, and the sale of surpluses, especially from the woolen mill, also linked the Community with the external world.

By 1900, 1,770 Amanites lived in a unique society. Separation engendered eccentricity. Travel was uncommon between the villages except by the Elders, and there is some evidence of limited contact within the villages. A peculiar Middle GermanUpper German dialect was spoken throughout the villages, and insiders even detected significant variations in speech among the villages. Only Elders spoke sufficient English to conduct business with the world outside. Distinctive clothing, furniture, music, and architecture rounded out Amana's folk culture. ${ }^{7}$

ARCHITECTURE, the enclosure and decoration of space, was essential to Amana's personality. Although the tendency to orient the buildings to one broad street with straggling appendages left a special impression on outsiders, the Strassendorf arrange-

6. Shambaugh, 175.

7. Andelson, "Double Bind," 449; Shambaugh, 142-44, 183, 266-68, 272, 318 n 142; Yambura, 51; Rettig, 109; Marjorie K. Albers, Old Amana Furniture (Shenandoah, IA, 1970), 62-66. 
ment, as it was called, was common to other German settlements. ${ }^{8}$ However, a unique system of wooden plank paths between houses and communal kitchens was arranged within blocks around the village church, as if to guard the communal buildings and focus social activity within the village by random meetings on the paths. The single-family aspect of the houses belied the fact that three to four families lived in each one, something that often fooled outside observers. Perhaps the Elders encouraged this impression to avoid the equation of sexual promiscuity and communalism suffered by societies with communal housing. Permission for each family to treat its portion of the house as a separate home helped render communalism tolerable. Certainly, the simulated single-family home illustrates the pragmatism that Amanites and others credited with supporting the Community's persistence. ${ }^{9}$

Building construction also mixed outside practices and those of the Community. The similarity in gross traits, form, materials, and feeling conveys a truly undifferentiated quality appropriate to communal architecture. But scrutiny of details discloses peculiar sequences for bonding bricks and patterns of framing, window mullions, and dormer types probably acquired variously from medieval German practices before relocation to the United States and from New England practices in Ebenezer. The amalgam has been labeled the Amana style. ${ }^{10}$

Amana's self-containment was first jeopardized from within by inconsistencies between the Elders' doctrines and their practices. The consequent dissolution of the governing board's moral force eroded the prohibitions against worldly goods introduced by outsiders. Some of the first were farmers who, with wool for the mill in Main Amana, brought their families on vacation to stay in the village hotel. Contact multiplied from other technologies, including two railroads, the telegraph, the telephone, and the printing press's newspapers, magazines, 159.

8. John Fraser Hart, The Look of the Land (Englewood Cliffs, NJ, 1975),

9. Delores Hayden, Seven American Utopias: The Architecture of Communitarian Socialism, 1790-1975 (Cambridge, MA, 1976), 225, 238, 243; Rettig, 32; Shambaugh, 136.

10. Claire Benjamin Watson, "The Architecture and Minor Arts of the Amana Society" (M.A. thesis, University of Colorado, 1946), 35-84; Claire Watson, "The Amana Style in Architecture," Iowan 7 (June-July 1959), 19, 21. 
and mail order catalogues. All of these incursions threatened Amana's folk culture, and the result was accelerated by the demands of the young who wanted worldly goods. ${ }^{11}$

The automobile further threatened Amana's culture. It easily penetrated the villages and hastened the end of Amana's defensive isolation. Contact with the outside world increased, and new disrespect for established authority resulted. As the Elders relaxed their prohibitions, village street crossings, which had been raised to discourage autos, were lowered about 1918. At first only Amana doctors and farm managers owned autos, although these amounted to no more than a dozen before the Great Change. Outsiders working in the villages probably introduced willing children to the delights of auto travel by offering them short rides. At least one young girl characterized those who came by auto as "more glamorous 'outsiders.'"12 In 1929 U.S. 6 was laid past Homestead and South Amana to connect Des Moines on the west and Davenport on the east. In 1931 Iowa 149 followed from Homestead past Main Amana north to Cedar Rapids. The admonition against vanity, which required that Amana's houses remain unpainted, merely embarrassed one youth after the highway construction. He argued that passersby must think Amanites could not afford paint and "turn up their noses at us and drive straight through. An unpainted town is a bad advertisement." 13

The automobile altered more than Amanites' perception of their existing architecture. At the south edge of South Amana, near the dirt road later paved as U.S. 6, Fred Setzer opened Amana's first garage in 1925 or 1926 in an adapted blacksmith shop. By 1929 business outgrew the makeshift blacksmith shop, and Setzer constructed a special building with the help of several men, including at least Dan Berger, George Young, Herbert Zuber, and Zuber's father. Although the board of trustees probably authorized the novel decision for a special building to serve

11. Andelson, "Double Bind," 116-122; Charles Nordhoff, The Communistic Societies of the United States (1875; reprint, New York, 1965), 405; Rettig, 7-8.

12. Millard Millburn Rice, "Eighty-Nine Years of Collective Living," Palimpsest 52 (1971), 205; Arthur Barlow, "Recollections: The Amana Society's 'Great Change,'" 1971, 15, Amana Heritage Society, Amana; Dan Berger, interview with author, 20 September 1980; Yambura, 94, 100 (quote).

13. Rettig, 9. 


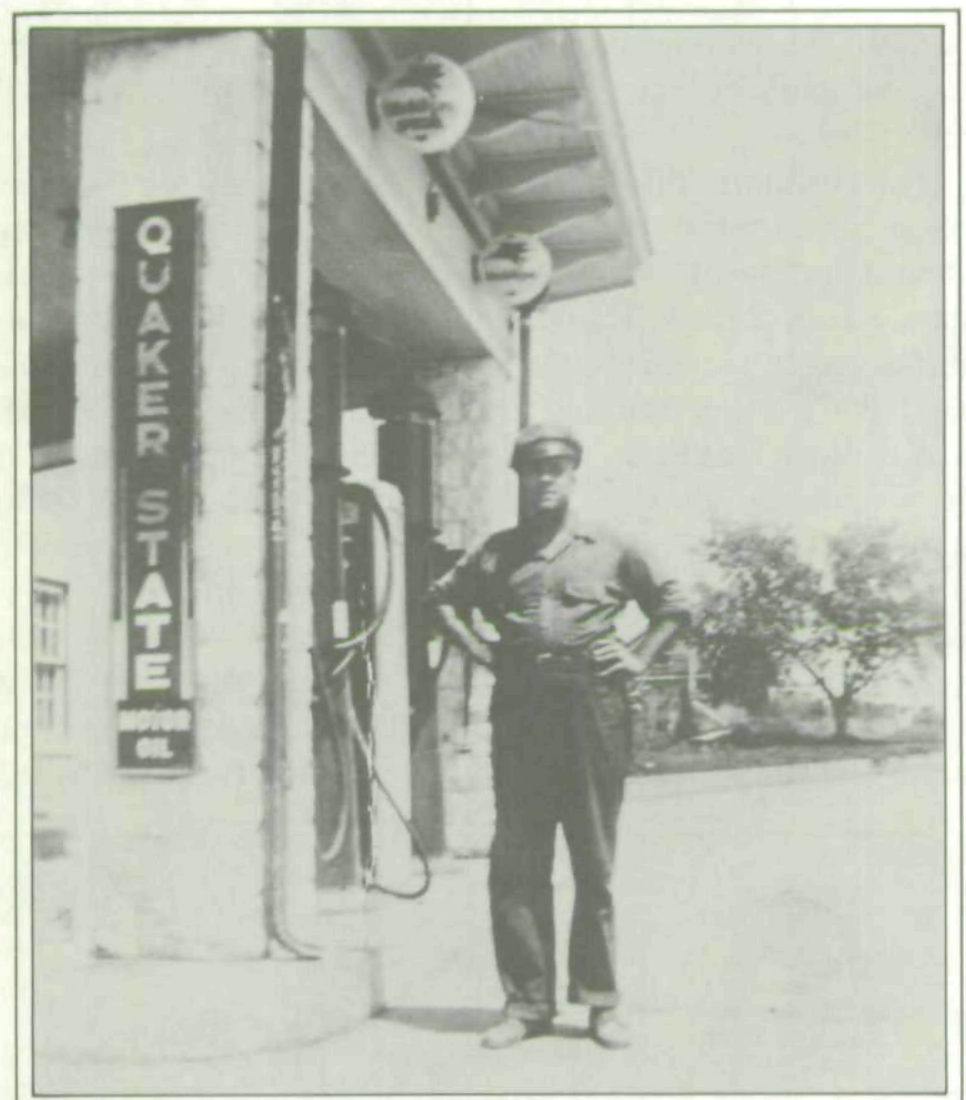

Fred Setzer at the South Amana garage, c. 1940. Note the projecting canopy overhead. Photo courtesy William F. Setzer.

the forbidden automobile, they departed radically from past practices either by providing an unsympathetic design or by abdicating to Setzer responsibility for the design. Heretofore, the Elders probably had dictated basic architectural proportions for every building, but, perhaps consistent with their relaxed authority at the time, they may have left the new building type to the man who best knew the function for which it was created. Setzer's only acquaintance with construction was as a "timber boss" who cut lumber for building. That did not equip him for the informal code by which Amana builders for eighty years had generated virtually identical buildings regardless of function. ${ }^{14}$

14. Hayden, 251. 
Fred Oehl, Sr., who was versed in this code as a carpenter, apparently restricted his contribution to the garage to designing the roof trusses.

The distinctly different form and materials for the South Amana garage produced the first break with the Amana style and signaled decay in the architectural consensus underlying Amana's folk culture. The garage, with a long, low, side profile surmounted by a moderately pitched roof and stepped gables, looked like no other building in the colony. Setzer's crew molded concrete blocks for the walls, thus making the garage one of the first concrete buildings in Amana. (Only one house in Middle Amana and one building in Upper South Amana-a separately platted settlement administered as part of South Amana-are remembered as earlier concrete structures.) When a white, water-proof paint and a trapezoid-shaped canopy projecting about twenty feet from the building were added in 1930, South Amana's garage looked like many others in the rural Midwest. ${ }^{15}$

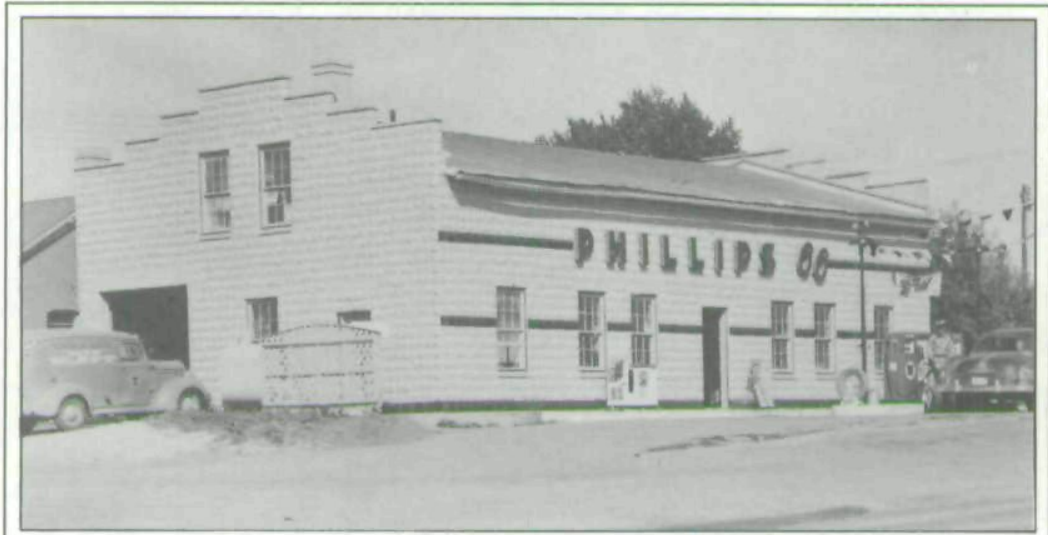

The South Amana garage, c. 1950. Photo courtesy the Museum of Amana History.

15. The unfortunate absence of written records for the period from 1923 to 1931 (Andelson, "Communalism," 360) coincides with the start of the South Amana garage. I have relied on the memories of Dan Berger, principally, and also Herbert Zuber for knowledge of the design process for this building. Zuber and Berger, a nephew of Fred Setzer, who designed and built the garage, both helped construct the building in 1929 and worked there beginning in 1930. Zuber left the garage in March 1931 and Berger in November 1932 when he became manager of the Main Amana oil station. Unless otherwise noted, interviews with Berger (2 August 1980, 20 September 1980, 12 July 1983) and with Zuber (12 July 1983) provide the factual basis for the discussion above. 
THE POLITICAL AND ECONOMIC CHANGES known as the Great Change formally ended Amana's folk culture. To ease the critical passage, the new leadership counseled a conservative evolution and stipulated a seven-month transition period from May 2, 1932, to January 1, $1933 .{ }^{16}$ During those months further reception of the automobile into Amana's new culture threatened the conservative policy on several grounds. The first was economic. Within the first week of the new Amana Society corporation, its outside business manager from Cedar Rapids, Arthur Barlow, lectured against the outward flow of capital likely to result from a sudden rush for long prohibited luxuries and singled out the automobile for special caution. ${ }^{17}$ Henry G. Moershel, prominent Amanite and president of the new corporation, somewhat contradicted Barlow's admonition only a week later by noting that the chance for automobile ownership could be one of the advantages of the Great Change. Amanites agreed. By the end of the transition period over one hundred bought autos, and by the end of the initial rush for luxuries in 1936 there were two cars for every nine Amanites. ${ }^{18}$

Servicing the automobile threatened no revolution. No stigma attached to the work. Since the 1920 s gasoline had been sold at curbside pumps throughout the villages, and the garage at South Amana had repaired autos. Therefore, Barlow was consistent with his evolutionary policy when, early in the transition period, he recommended construction of two oil stations, as they were known locally. ${ }^{19}$ But the decision of the proper architectural style in which to clad these stations at Homestead and Main Amana disclosed how far Amana's native leaders had departed from their folk moorings.

As before, Amana's leaders decided the issue, but a considerable difference of opinion quickly emerged among the new leaders on the four-member executive committee of the Amana

16. Henry G. Moershel, "Amana's Heritage," typewritten MS, 1969, 1, Amana Heritage Society; Rettig, 22-23.

17. Amana Society Corporation News Bulletin 1, no. 14 (1932), 1 (hereafter cited as Bulletin).

18. Bulletin 1, no. 5 (1932), 1; Rettig, 33, 40; Davis, 228.

19. Berger, interviews with author, 2 August 1980, 20 September 1980; Barlow, "Recollections," 15; Herbert Fels, interview with author, 20 September 1980. Fels operated the Homestead oil station from its beginning in 1932 until his retirement in 1953. 
Society. Arthur Barlow apparently acquired the committee's acceptance of the new oil station business with ease when he submitted the bids from several competing petroleum suppliers. But an exchange about an appropriate design for the stations resulted. This may have occurred just after the new Amana Society unofficially began on May 2, 1932, and before June 6, 1932, when Barlow's presentation of the suppliers' bids to the full board strongly suggests the executive committee's prior authorization of the oil stations. ${ }^{20}$ In the initial encounter, Barlow, the outsider and financial expert, ironically insisted on the Amana style for the oil stations against the urging of Henry G. Moershel to adopt the roadside architecture of the outside world. The other three committee members apparently listened in thoughtful silence. ${ }^{21}$

Barlow's design policy was consistent with his conservative course throughout the critical transition. He expressed genuine affection for the Amana folk culture at the start of the Great Change even though he was one of the chief engineers of modernization. His sense of the Amana style was as an architecture whose "lines are simple." In its defense he recalled recent praise by the famous local artist Grant Wood, who as an ardent spokesman for regionalism opposed crass roadside commercialism. Revival of the Amana style in the Society's roadside architecture

20. "Minute Book: Board of Directors of Amana Society," vol. 1, May 2, 1932-February 13, 1933, 64, Amana Society Headquarters, Amana (hereafter cited as "Minute Book").

21. The absence of written records for the executive committee leaves uncertain the exact days on which that body discussed the design issue. Time ranges, however, can reasonably be inferred from my interviews with Arthur Barlow (9, 23 August 1980) and the "Minute Book." Barlow's interviews constitute an important record of the discussion on design of the oil stations. The Des Moines Register noted that "there were some" who favored adoption of standard filling station design-as if several people did so (quoted in Rettig, 33). Other sources, however, contain no evidence that anyone but Henry G. Moershel favored departure from the Amana architectural norm. Barlow's official account of the Great Change discloses no controversy; in it he mentions only one meeting of the executive committee about the oil stations and implies agreement about their number, locations, and styles (Barlow, "Recollections," 15-16). Despite Barlow's effort to conceal Moershel's identity, an inadvertent reference to the opponent on the design issue as a president whose wife was alive at the time of the interview revealed Moershel's identity. The Barlow interviews form the basis for the discussion above; interpretation of their meaning, however, is mine alone. 
was no clever strategy Barlow devised to lure trade with a quaint landscape. He repeatedly insisted profit was not the motive for his advocacy of oil stations in the Amana style. Surely, he did not want to interrupt Amana's special "atmosphere," as he called it, and doubtless he had seen examples of the latest filling stations which deliberately contrasted with their environment to overcome the difficulties of attracting business in the depressed economy of the 1930s. Although it can be reasoned that Barlow foresaw the potential of tourism to help rejuvenate Amana's economy, there is no evidence that he was motivated in 1932 to start the oil stations to help attract tourists. Indeed, very concerned with the financial balance, Barlow was probably alarmed at the immediate failure of Amanites to refuel at their stations. He did not manipulate Amana's culture for profit. He wanted Amana to survive despite the automobile and he sincerely believed in the reciprocal benefits of the financial and cultural realms for Amana's total welfare. ${ }^{22} \mathrm{He}$ came close to articulating this philosophy in a few presentations at a series of village meetings in late December 1934 and early January 1935: "While my duties are with the business corporation, I would like, if I may, to urge each of you to hold fast to a spiritual or religious life. If you do, I am sure the business side of Amana society and whole community will fare better." ${ }^{23}$ In this simply worded yet profound statement, Barlow linked himself with the Amana tradition of pragmatic leadership.

Henry G. Moershel was also consistent with his own more rapid pace in improving Amana's welfare when he advocated filling station architecture seen elsewhere. Moershel had been the single most effective spokesman for the Great Change. Regarding roadside architecture, he may have been encouraged by the South Amana garage's departure from the folk pattern. Moershel wanted "gas stations with gables," like the "Phillips

22. Cedar Rapids Gazette, 20 July 1932, clipping in Barlow scrapbook, Amana Heritage Society, Amana, Iowa; John A. Jakle, "The American Gasoline Station, 1920-1970," Journal of American Culture 1 (1978), 529-30; Barlow, "Recollections," 6, 13, 25; Bulletin 1, no. 27 (1932), 1.

23. Informal Community Meetings Held Throughout the Seven Villages, [1935], 6. This document is a published pamphlet now available at the Amana Heritage Society. 


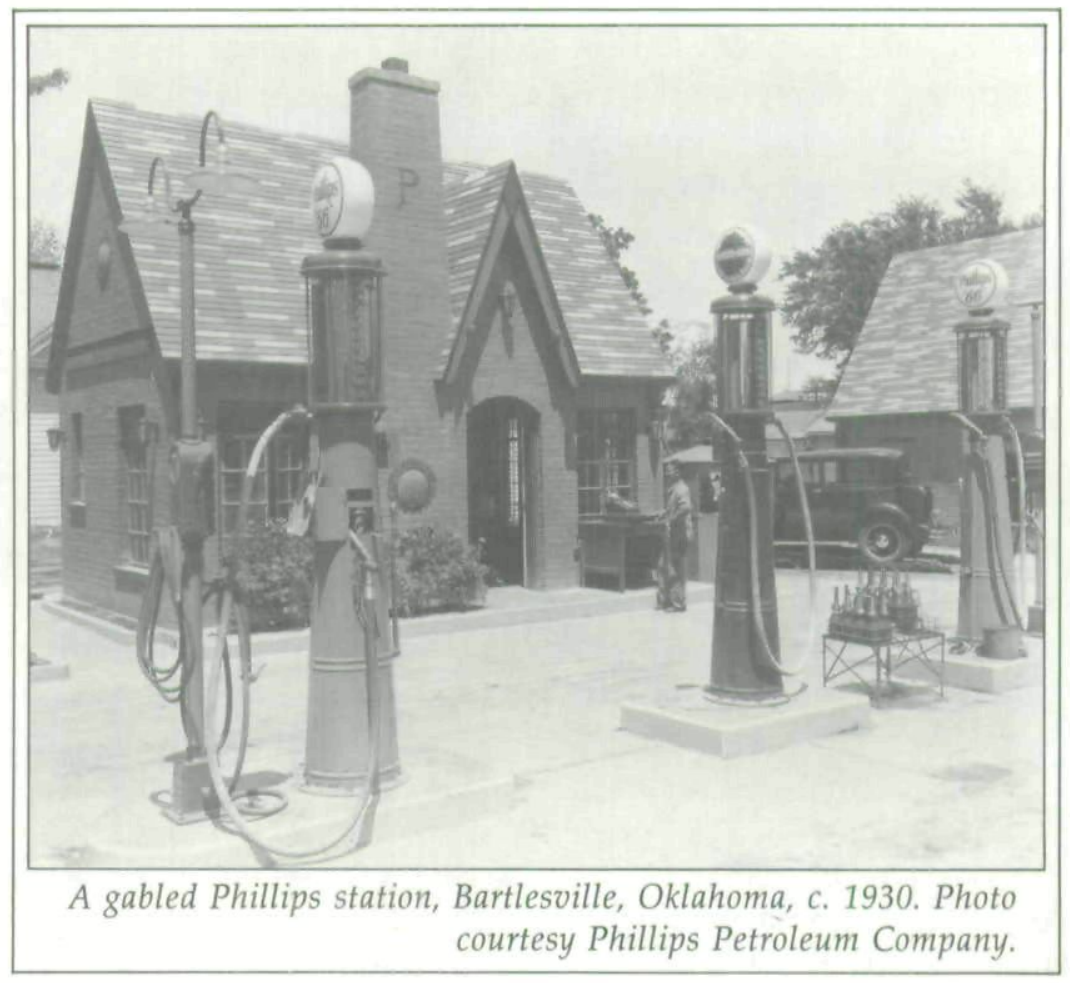

type." If he hoped Amana might overcome some of its backwardness by adopting a contemporary design, it should be noted that the "Phillips type" recalled the revival styles which were no longer counted as the most advanced in the filling station trade of the 1930s; Moershel was essentially conservative. He also did not insist that his view about the oil station style prevail. By July 29, 1932, the executive committee had authorized Barlow to proceed with his conservative oil station design. ${ }^{24}$

Under a subcommittee of the board of directors, including Barlow, actual work on the buildings proceeded smoothly. Only the exact location in Homestead raised some question, and that

24. Andelson, "Communalism," 367, 370, 376; Jakle, 529-30; Keith A. Sculle, "The Pure Sign," Journal of American Culture 5 (1982), 89. It is impossible to know exactly when the executive committee accepted Barlow's design solution. July 29, 1932, is the last probable date because the contract with Midway Oil Company was awarded sometime between July 14 and 29 and the company's former representative for Amana remembered that Midway accepted Barlow's design for the oil station after the contract was signed ("Minute Book," 84, 98; Francis Wakefield, interview with author, 9 August 1980). 
only momentarily. ${ }^{25}$ Barlow's instinct for the Amana style also determined materials. While the Calico Print Shop in Main Amana lay in ruins following a fire, Barlow ordered some of its brick salvaged for the oil stations. He shared the folk building code sufficiently to sound like an Amana builder when he implied that the choice of brick ensured integrity of design: "To me it was a natural." 26 That a former station manager later relied on the bricks to mistakenly identify the Main Amana station as an adapted colony house only underscores the success of Barlow's sensitive choice..$^{27}$ Construction began at Homestead on August 10, 1932, and five days later at Main Amana. Employment of Fred Oehl, Sr., project supervisor; Jacob Herr, local construction manager for Homestead; and John H. Haas, Sr., construction manager for Main Amana-all Amana builders-probably determined the final details, perhaps including the adaptation of the Amana house trellis to screen restroom entrances. Both stations were officially announced open on November 10, 1932. Nearly fifty years later, Barlow acknowledged "a pleasant feeling of public acceptance that [Amana] built gas stations as [it] did." 28

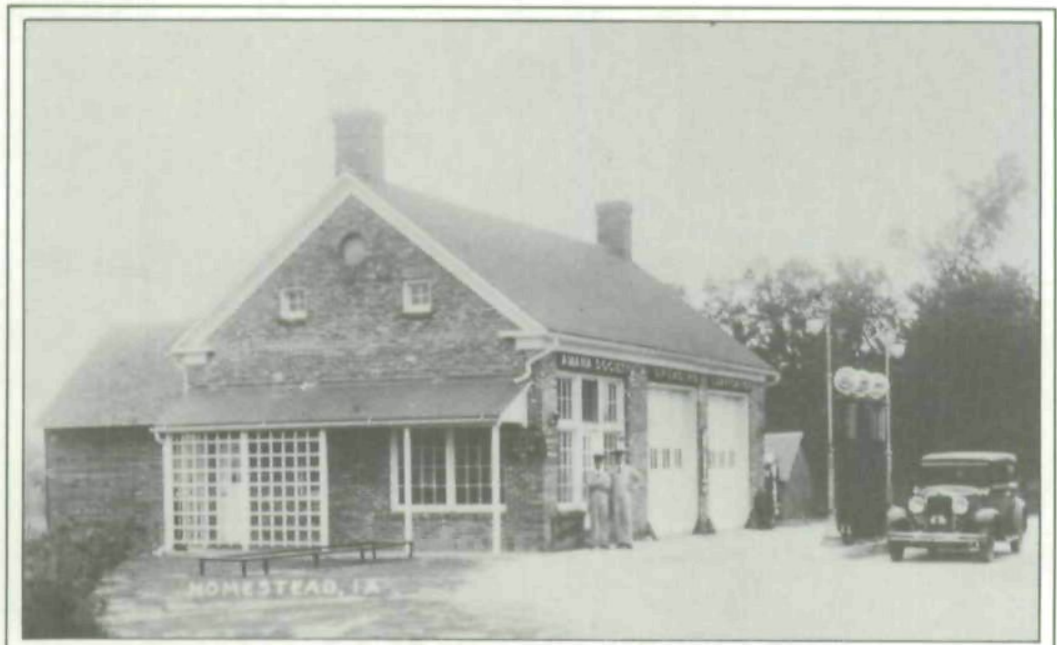

The Homestead oil station, 1932. Photo courtesy the Amana Society.

25. Bulletin 1, no. 14 (1932), 1.

26. Barlow interview, 9 August 1980.

27. Lynn Trumpold, interview with author, 2 August 1980.

28. Bulletin 1, no. 27 (1932), 1; Barlow interview, 9 August 1980. 
Amana required spatial management. Its folk culture was born in virtual isolation and flourished by evolving a set of separate villages with sufficient proximity for a common identity, including the enclosure and decoration of space in the Amanastyle architecture. Problems at the religious heart of the culture, however, opened it to disruptive outside influences conveyed by a succession of alien technologies including the automobile. Autos spawned the first architectural threat by the roadside, the garage at South Amana. Under the unlikely direction of a sympathetic outsider, however, Amana's native leaders led the critical transition during the Great Change away from a folk culture by enfolding the next roadside buildings, the oil stations at Homestead and Main Amana, in Amana-style architecture. Thus Amana's habitually pragmatic adjustment to alien influences reasserted the Amana determination to survive. 
Copyright of Annals of Iowa is the property of State of Iowa, by \& through the State Historical Society of Iowa and its content may not be copied or emailed to multiple sites or posted to a listserv without the copyright holder's express written permission. However, users may print, download, or email articles for individual use. 